\title{
Prevalence of malocclusion and assessment of treatment needs in $\beta$-thalassemia major children
}

\author{
Deepak Kumar Gupta ${ }^{1 *}$, Satinder Pal Singh ${ }^{2}$, Ashok Utreja $^{2}$ and Sanjeev Verma ${ }^{1}$
}

\begin{abstract}
Background: The objective of this study is to evaluate the prevalence of malocclusion and treatment needs in transfusion dependent $\beta$-thalassemia major children.

Methods: One hundred transfusion dependent $\beta$-thalassemia major children visiting the Department of Pediatrics were selected randomly and evaluated for malocclusion with Angle's classification and Dewey's modification. The orthodontic treatment needs were also assessed using Grainger's treatment priority index (TPI). The orthodontic treatment needs were compared to normal children.

Results: The assessment of treatment needs revealed a higher prevalence of handicapping and severely handicapping malocclusion in thalassemic children compared to normal children. The thalassemic patients were found to show significantly more Angle's Class II malocclusion (55 \% vs. $15.7 \%$ ) when compared to normal children.

Conclusions: The higher prevalence of Angle's Class II malocclusion and definitive malocclusion in thalassemic children indicates the importance of preventive orthodontic procedures and efforts towards providing orthodontic treatment to these children.
\end{abstract}

Keywords: Prevalence, Thalassemia, TPI index, Malocclusion

\section{Background}

Orthodontics is the discipline within the framework of dentistry which has for its purpose the diagnosis and treatment of dentofacial abnormalities. This twofold purpose is best expressed in those children who either exhibit a dentition of extreme degree of malocclusion or facial features of marked variations. When a child exhibits both extremes, he deserves a thorough study of his affliction. A child with thalassemia major (Cooley's anemia) falls in such group [1].

Thalassemia is one of the commonest genetic disorders known to mankind. Thalassemia and other hemoglobinopathies are widespread globally. Thalassemia may have originated 50,000 years ago in a valley South of Italy and Greece covered by Mediterranean Sea. The name thalassemia has been derived from a Greek word "Thallus" meaning sea.

\footnotetext{
* Correspondence: gupta_drdeepak@yahoo.com

${ }^{1}$ Department of Orthodontics and Dentofacial Orthpaedics, Dr Harvansh Singh Judge Institute of Dental Sciences and Hospital, Panjab University, Chandigarh, India

Full list of author information is available at the end of the article
}

Thalassemia was recognized as a clinical entity by Cooley and Lee. Thomas B. Cooley (1927), a pioneer pediatrician, reported seven cases of splenomegaly with anemia, peculiar bone changes, and characteristic facies [2]. Originally described as a separate disease entity, this disease is now known as Cooley's anemia or $\beta$-thalassemia major. The term "thalassemia" refers to a group of blood disorders characterized by decreased synthesis of one of the two types of polypeptide chain ( $\alpha$ or $\beta$ ) which form the normal adult hemoglobin molecule $\left(\mathrm{HbA}, \alpha_{2} \beta_{2}\right)$, resulting in decreased filling of the red cells with hemoglobin and anemia. Based on the genetic and clinical entities, thalassemia is classified as homozygous, heterozygous, or compound heterozygous [3]. The homozygous form (thalassemia major) exhibits most severe clinical symptoms with marked orofacial defects. The inheritance of beta thalassemia is an autosomal recessive disorder with the chromosomal abnormality on short arm of 11th chromosome (chromosome \# 11p15.5).

The suggested causes of growth retardation and maturation of the skeleton in thalassemic major patients include 
chronic anemia, hyperparathyroidism, and somatomedin deficiency, a factor that stimulates cartilage growth [4-6]. The dentition shows protrusion, flaring, and spacing of the anterior teeth, open bite, and other degrees of malocclusion [7]. The tooth crown size and crown length in thalassemic subjects are significantly smaller than those in the unaffected groups $[8,9]$. The literature shows increased prevalence and severity of malocclusion (dentional and craniofacial abnormalities) in thalassemic patients [8, 9]. Hattab $\mathrm{FN}^{1}$ observed increased overjet in $25.9 \%$ of the patients and more than half of the patients exhibited frontal bossing, saddle nose, and to less extent maxillary protrusion, giving in severe cases $(16.7 \%)$ a "chipmunk"like appearance [10]. The prevalence and severity of malocclusion is also dependent on the medical treatment provided to the thalassemic children [11]. Patients with craniofacial anomalies often have appearance concerns and related social anxiety which can affect their quality of life. Singh and Moss in their study assessed the psychological impact of facial and dental appearance in patients with craniofacial anomalies in comparison to a general population control group [12]. It is thus important to study the prevalence and orthodontic treatment needs in our population that may be different from other groups. The treatment priority index (TPI) index was used in the study because of its simple and efficient application in epidemiological surveys of malocclusions without undue cost and energy [13].

Thus, the aim of the present study was to evaluate the prevalence of the type of malocclusion and to assess orthodontic treatment needs in the thalassemic children.

The study was carried out with the following aims and objectives:

1. To evaluate the prevalence of malocclusion in transfusion-dependent beta thalassemia children using Angle's classification and Dewey's modification

2. To assess the orthodontic treatment needs using Grainger's TPI

\section{Methods}

The study was conducted at the Unit of Orthodontics, Oral Health Science Centre in collaboration with Thalassemia ward at Department of Pediatrics, Advanced Pediatric Centre (APC), Postgraduate Institute of Medical Education and Research (PGIMER), Chandigarh. Appropriate ethical clearance was granted to conduct the study by the board of studies of the institution. The study comprised of one hundred transfusion-dependent beta thalassemia major children (71 males, 29 females) between the age range of 12-17 years. The mean age of sample was 13.84 years. The children were selected on a random basis from the patient regularly coming for transfusion in the thalassemic ward at APC, PGIMER, Chandigarh.
The first 100 beta thalassemia patients visiting the department in the defined age group were assigned to the examiner for evaluation of type of malocclusion and TPI index, without the examiner's choice. The examiner was trained and standardized in the use of TPI. The intraoral examination of all the patients was done and recorded by the same examiner.

\section{Selection criteria}

The patients included in this study fulfilled the following criteria:

(i) Diagnosed case of homozygous beta thalassemia (thalassemia major), receiving regular blood transfusion.

(ii) Patients 12-17 years of age.

(iii) Patient who had not undergone any kind of orthodontic treatment.

(iv) Patient not affected by conditions like gross physical or mental disability.

(v) The first 100 patients visiting the department regularly for transfusion every month were evaluated. They constituted the major portion of the patients in the concerned age group visiting the thalassemia clinic for regular transfusion.

The control group comprised a proportioned sample from epidemiological survey of prevalence of malocclusion in 12-17 years school children; 500 students in the defined age group were examined randomly in the two different schools in the vicinity without any priority, and the data was recorded.

A Performa was used to record the various aspects of malocclusion and to record the various parameters of Grainger's TPI index [14]. The Performa (TPI data collection form) was designed to include patient details, type of malocclusion i.e. Angle's classification, and parameters of TPI index (first molar relation, horizontal and vertical incisor relation, tooth displacement score, congenitally missing incisors, posterior crossbite, and any other defect.

A total of TPI scores were calculated, and the level of severity was assessed according to malocclusion severity estimate. Levels of severity of a malocclusion as established by the malocclusion severity estimate (MSE) and used for the present study are given below:

\begin{tabular}{lc}
\hline I. Virtually classic normal occlusion & 0 \\
$\begin{array}{l}\text { II. Minor manifestations of malocclusion and treatment need is } \\
\text { slight }\end{array}$ & $1-3$ \\
III. Definite malocclusion, but treatment elective & $4-6$ \\
IV. Severe handicap, treatment highly desirable & $7-9$ \\
V. Very severe handicap with treatment mandatory & $>10$ \\
\hline
\end{tabular}


Table 1 Comparison of prevalence of Class I, Class II, and Class III malocclusion in thalassemic and normal children

\begin{tabular}{|c|c|c|c|c|c|c|c|c|c|c|c|c|c|c|c|c|c|}
\hline & \multicolumn{8}{|c|}{ Angle's Class I Dewey's modification } & \multicolumn{5}{|c|}{ Angle's Class II } & \multicolumn{4}{|c|}{ Angle's Class III } \\
\hline & $\begin{array}{l}\text { Class I type } \\
1(\%)\end{array}$ & $\begin{array}{l}\text { Class I type } \\
2(\%)\end{array}$ & $\begin{array}{l}\text { Class } 1 \text { type } \\
3(\%)\end{array}$ & $\begin{array}{l}\text { Class I type } \\
4(\%)\end{array}$ & $\begin{array}{l}\text { Class I type } \\
5(\%)\end{array}$ & $\begin{array}{l}\text { Bimax } \\
(\%)\end{array}$ & $\begin{array}{l}\text { Spacing } \\
(\%)\end{array}$ & $\begin{array}{l}\text { Total } \\
\text { (\%) }\end{array}$ & $\begin{array}{l}\text { Class II } \\
\text { Div } 1 \text { (\%) }\end{array}$ & $\begin{array}{l}\text { Class ॥ } \\
\text { Div } 2(\%)\end{array}$ & $\begin{array}{l}\text { Class II subDiv } \\
1(\%)\end{array}$ & $\begin{array}{l}\text { Class II subDiv } \\
2(\%)\end{array}$ & $\begin{array}{l}\text { Total } \\
(\%)\end{array}$ & $\begin{array}{l}\text { Type } 1 \\
(\%)\end{array}$ & $\begin{array}{l}\text { Type } 2 \\
(\%)\end{array}$ & $\begin{array}{l}\text { Type } 3 \\
(\%)\end{array}$ & $\begin{array}{l}\text { Total } \\
(\%)\end{array}$ \\
\hline $\begin{array}{l}\text { Thalassemic } \\
\text { children }\end{array}$ & 25 & 8 & 0 & 2 & 0 & 5 & 4 & 44 & 34 & 5 & 15 & 1 & 55 & 0 & 0 & 1 & 1 \\
\hline $\begin{array}{l}\text { Normal } \\
\text { children }\end{array}$ & 69 & 9 & 0.4 & 0.9 & 0.59 & 8 & 12 & 82.2 & 6 & 3.69 & 4 & 2 & 15.69 & 0.6 & 0.49 & 0.4 & 1.49 \\
\hline
\end{tabular}




\section{Statistical analysis \\ Intraexaminer and interexaminer variability and reproducibility}

The observations in TPI index of approximately $10 \%$ of the sample were graded after an interval of 1 week to standardize the investigator for a reproducible result. The investigator was trained for evaluation using TPI index. Further, the observations of $10 \%$ patients were also graded by one of the experienced examiners so as to test the interexaminer reproducibility which was found to be satisfactory.

The means and percentages were calculated for the different population groups. The comparison of population means was done using " $Z$ " test to compare the prevalence of malocclusion and malocclusion traits between the two groups under study.

\section{Results}

\section{Prevalence of malocclusion}

The results in the present study show that significantly less $(p<0.001)$ thalassemic children have Angle's Class I malocclusion (44.0 \% vs $82.2 \%$ ) than normal children. The thalassemic patients show significantly more Angle's Class II malocclusion (55 \% vs $15.7 \%$ ) when compared to normal children (Table 1).

Further within the Class I malocclusion group, Class I type 1 malocclusion was significantly less $(p<0.001)$ in thalassemic children when compared to normal (25\% vs $69.6 \%)$.

In the Class II subgroup, Class II div 1 malocclusion shows the maximum occurrence.

The prevalence of Class III malocclusion is less than the normal population with only one case reported in the present study (Table 1).

\section{Assessment of overjet, prevalence of tooth displacement, and buccal and lingual crossbite}

In thalassemic children, a positive overjet was found in $99.0 \%$ of patients and it was not different from normal population $(98.5 \%)$. None of the thalassemic patients showed overjet of $1 \mathrm{~mm}$ compared to $3.9 \%$ of normal children having overjet of $1 \mathrm{~mm}(p<0.05)$. The prevalence of tooth displacement is more in thalassemic patients. The prevalence of buccal and lingual crossbite is also more in thalassemic patients (Table 2).

\section{Treatment needs assessment}

TPI scores showed normal occlusion (TPI score 0 ) to be significantly less $(p<0.001)$ in thalassemic children when compared to normal children. On the other hand, definite malocclusion (TPI scores 4-6.99) was significantly more in thalassemic children compared to normal children. Similarly handicapping malocclusion (TPI scores 7-9.9) and severely handicapping malocclusion (TPI scores $>10)$ was significantly more $(p<0.05)$ prevalent in thalassemic children than normal children (Table 3 ).

The comparison of TPI score of thalassemic children in the present study shows $32 \%$ in the no or minor malocclusion groups, $36 \%$ in the definite malocclusion group, and $32 \%$ in the handicapping and severely handicapping malocclusion group.

Similar comparison of TPI score of normal children in the present study shows $77 \%$ in the no or minor malocclusion groups, $10 \%$ in the definite malocclusion group and $8 \%$ in the handicapping and severely handicapping malocclusion group.

\section{Discussion}

The prevalence and severity of malocclusions in transfusion-dependent thalassemic patients of the age group 12-17 years was done as this is a common age when orthodontic treatment is sought. The TPI was selected for this evaluation as it has proved to be a useful epidemiological indicator of malocclusion [15]. It has been found to be highly reproducible and valid [16]. Application of the TPI is practicable and requires less clerical time when compared with the Occlusal Index (OI) [17]. Thus, the TPI is a useful index for measuring need for treatment and as an aid in the identification of children who can benefit most from orthodontic treatment [14].

The present study reported a ratio of 1:1.25:0.01 between angle Classes I, II, and III malocclusion, respectively, in the thalassemia group which contrasted to a normal population ratio of 5.2:1:0.01. Pusaksrikit et al. reported the ratio between various angle classes, i.e., I, II, III as 2.7:1:0 which contrasted to a normal population pattern of 3:1:1 [18].

Giuseppina in a study reported Class I, II, III malocclusions, and asymmetries in 40.4, 29.2, 3.2 and $27.1 \%$ of the sample, respectively. The objective need for

Table 2 Comparison of prevalence of tooth displacement, buccal and lingual crossbite, and overjet in thalassemic and normal children

\begin{tabular}{|c|c|c|c|c|c|c|c|c|c|c|c|c|c|c|}
\hline & \multicolumn{5}{|c|}{ Tooth displacement } & \multicolumn{2}{|c|}{ Buccal crossbite } & \multicolumn{2}{|c|}{ Lingual crossbite } & \multicolumn{5}{|c|}{ Overjet } \\
\hline & $\begin{array}{l}1- \\
2\end{array}$ & $\begin{array}{l}3- \\
4\end{array}$ & $\begin{array}{l}5- \\
6\end{array}$ & $\begin{array}{l}7- \\
8\end{array}$ & $>9$ & $\begin{array}{l}\text { Single tooth } \\
(\%)\end{array}$ & $\begin{array}{l}\text { Total prevalence } \\
(\%)\end{array}$ & $\begin{array}{l}\text { Single tooth } \\
(\%)\end{array}$ & $\begin{array}{l}\text { Total prevalence } \\
(\%)\end{array}$ & 1 & $\begin{array}{l}2- \\
4\end{array}$ & $\begin{array}{l}5- \\
6\end{array}$ & $\begin{array}{l}7- \\
8\end{array}$ & $>9$ \\
\hline $\begin{array}{l}\text { Thalassemic } \\
\text { children }\end{array}$ & 8 & 30 & 42 & 10 & 10 & 17 & 20 & 17 & 21 & 0 & 48 & 32 & 14 & 6 \\
\hline Normal children & 30 & 18 & 8 & 5 & 2 & 2 & 3 & 3 & 4 & 4 & 83 & 8 & 4 & 1 \\
\hline
\end{tabular}


Table 3 Comparison of TPI scores in thalassemic and normal children

\begin{tabular}{llllll}
\hline TPI scores & $\begin{array}{l}\text { Normal occlusion } \\
0(\%)\end{array}$ & $\begin{array}{l}\text { Minor malocclusion } \\
1-3.99(\%)\end{array}$ & $\begin{array}{l}\text { Definite malocclusion } \\
4-6.99(\%)\end{array}$ & $\begin{array}{l}\text { Handicapping malocclusion } \\
7-9.99(\%)\end{array}$ & $\begin{array}{l}\text { Severely handicapping } \\
\text { malocclusion }>10.0(\%)\end{array}$ \\
\hline Thalassemic children & 6 & 26 & 36 & 18 & 14 \\
Normal children & 40 & 37 & 10 & 5 & 3 \\
\hline
\end{tabular}

orthodontic treatment (grades 4 and 5 of IOTN) was registered in 1077 subjects (41.2\%) [19].

The higher prevalence of Class II malocclusion in thalassemic children in the past has been attributed both to marrow hyperplasia occurring due to chronic anemia, resulting in maxillary prominence and also due to mandibular retrusion occurring because of generalized growth retardation in the thalassemic children by different authors [20-23].

In the present study, the assessment of malocclusion using TPI scores in normal population shows no or minor malocclusion in $77 \%$ cases. This is similar to results of studies by Bhardwaj et al., Shivakumar et al., Esa et al., and van Wyk et al. These studies using Dental Aesthetic Index scores show no or minor malocclusion in the range of 60 to $80 \%$ in the normal population [24-27]. Ugur et al. conducted a study to evaluate the prevalence of malocclusion and to assess the need for orthodontic treatment among 6-10-yearold Turkish primary school children. The TPI was used to record and measure the malocclusions; $40.38 \%$ of the observed population showed normal occlusion, $21.85 \%$ had minor manifestations of malocclusion and treatment need was slight, $25.17 \%$ of the subjects showed definite malocclusion, $7.54 \%$ had severe malocclusion, and $5.06 \%$ had a very severe handicap with a mandatory treatment requirement. Thus, according to this study, there is definite need for orthodontic treatment in $37 \%$ of individuals [28].

The present study indicates that $68 \%$ of the thalassemic patients definitely need orthodontic treatment which is $18 \%$ for normal population. Comparison with any of the previous studies show that the prevalence of malocclusion in thalassemic patients is also much more than that in the normal population. The assessment of treatment needs revealed a higher prevalence of handicapping and severely handicapping malocclusion in thalassemic patients compared to normal children. This necessitates the need for providing orthodontic treatment to these children.

In the present study, occurrence of Class III malocclusion was an interesting observation. It is difficult to explain this observation as there was no familial history and literature does not support the occurrence of Class III in thalassemic patients.

The present study was conducted in an environment where the patients are regularly transfused and transfusion is started at very early stages. The blood hemoglobin levels are regularly monitored and maintained. This decreases the extent of malocclusion. Thus, we may expect more severe malocclusions in other environments where the facilities for these patients are not very favorable. This may further increases the need for orthodontic treatment.

\section{Conclusions}

- The prevalence of Class II malocclusion is higher in thalassemic children.

- Overall definite malocclusion, handicapping malocclusion, and severely handicapping malocclusion is more in thalassemic children than that in normal children, so our efforts should be directed towards providing orthodontic treatment to these children.

- Further, the advancement of medical treatment modalities has led to an increase in life expectancy of these children and demand for orthodontic treatment may increase in future.

- These results underscore the high percentage of orthodontic treatment need in thalassemic patients and indicate the importance of preventive orthodontic procedures.

Since the sample size of the thalassemic group in the study was not very large, further studies may be conducted to confirm the results of the present study. The baseline information outlined in the present study can be appropriately utilized for the future planning to meet the orthodontic treatment need among the population.

\section{Competing interests \\ The author(s) declare that they have no competing interests.}

\section{Authors' contributions}

DG collected and assembled the data by clinical examinations of the sample. DG, SPS, and AU designed the study and interpreted the observations. SV participated in coordination and helped to draft the manuscript. All the authors read and approved the final manuscript.

\section{Acknowledgements}

The project was supported by Dr Ram Kumar Marwaha Professor, Department of Pediatrics, Advanced Pediatrics Centre, PGIMER, Chandigarh and allowed to conduct the research work.

\section{Author details}

${ }^{1}$ Department of Orthodontics and Dentofacial Orthpaedics, Dr Harvansh Singh Judge Institute of Dental Sciences and Hospital, Panjab University, 
Chandigarh, India. ${ }^{2}$ Unit of Orthodontics, Oral Health Sciences Centre, PGIMER, Chandigarh, India.

\section{Received: 29 June 2015 Accepted: 31 August 2015}

Published online: 09 March 2016

\section{References}

1. Asbell MB. Orthodontic aspects of Cooley's anemia. Ann Ny Acad Sci. 1964;119:662-3.

2. Cooley TB, Witwer ER, Lee P. Anemia in children with spenomegaly and peculiar changes in bones (report of cases). Am J Dis Child. 1927;34:347-63.

3. Cappellini MD, Cohen A, Eleftheriou A, et al. Guidelines for the Clinical Management of Thalassaemia [Internet]. 2nd Revised edition. Nicosia (CY): Thalassaemia International Federation; 2008. Chapter 1, Genetic Basis and Pathophysiology. Available from: http://www.ncbi.nlm.nih.gov/books/ NBK173971\%.

4. Weatherall JD, Clegg JB. The thalassemia syndromes. 3rd ed. Oxford: Blackwell Scientific Publications; 1981.

5. Caffey J. Cooley's anemia: a review of reentgenographic findings in the skeleton. Am J Roentgenology. 1957;78:381-91.

6. Flynn DM, Fairney A, Jackson D, Clayton BE. Hormonal changes in thalassemia major. Arch Dis Child. 1976;51:828-36.

7. Saenger P, Schwartz E, Markenson AL, Graziano JH, Levine LS, New MI, et al. Depressed serum somatomedian activity in beta-thalassemia. J Pediatr. 1980;96:214-8.

8. Kaplan RI, Werther R, Castano FA. Dental and oral findings in Cooley's anemia: a study of fifty cases. Ann N Y Acad Sci. 1964;119:664-6.

9. Tas I, Smith P, Cohen T. Metric and morphologic characteristics of the dentition in beta thalassemia major in man. Arch Biol. 1976;21:583-6.

10. Hattab FN. Periodontal condition and orofacial changes in patients with thalassemia major: a clinical and radiographic overview. J Clin Pediatr Dent. 2012:36(3):301-7.

11. Wolman IJ, Ortolani M. Some clinical features of Cooley's anemia patients related to transfusion schedules. Ann NY Acad Sci. 1969;165:407-14.

12. Singh VP, TP M. Psychological impact of visible differences in patients with congenital craniofacial anomalies. Prog Orthod. 2015;16:5.

13. Slakter MJ, Albino JE, Green LJ, Lewis E. A validity of an orthodontic treatment priority index to measure need for treatment. Am J Orthod. 1980;78:421-5.

14. Orthodontic treatment priority index; National Centre for Health Services; series 2; number 25 available from: http://www.cdc.gov/nchs/data/series/sr_ 02/sr02_025acc.pdf. accessed March 3,2016

15. Ghafari J, Locke SA, Bentley JM. Longitudinal evaluation of the treatment priority index (TPI). Am J Orthod Dentofacial Orthop. 1989;96:382-9.

16. Hermanson PC, Grewe JM. Examiner variability of several malocclusion indices. Angle Orthod. 1970;40:219-35.

17. Tang ELK, Wei SHY. Recording and measuring malocclusion: a review of the literature. Am J Orthod Dentofac Orthop. 1993;103:344-51.

18. Pusaksrikit $S$, Isarangkura P, Hathirat P. Occlusion of teeth in thalassemic patients. Birth Defects. 1988;23(5A):429-33.

19. Laganà G, Masucci C, Fabi F, Bollero P, Cozza P. Prevalence of malocclusions, oral habits and orthodontic treatment need in a 7- to 15-year-old schoolchildren population in Tirana. Prog Orthod. 2013;14:12.

20. Başsimitçi S, Yücel-Eroğlu E, Akalar M. Effects of thalassemia major on components of the craniofacial complex. Br J Orthod. 1996;23(2):157-62.

21. Toman HA, Nasir A, Hassan R, Hassan R. Skeletal, dentoalveolar, and soft tissue cephalometric measurements of Malay transfusion-dependent thalassemia patients. Eur J Orthod. 2011;33(6):700-4.

22. Amini F, Jafari A, Eslamian L, Sharifzadeh S. A cephalometric study on craniofacial morphology of Iranian children with beta-thalassemia major. Orthod Craniofac Res. 2007;10(1):36-44.

23. Abu Alhaija ES, Hattab FN, al-Omari MA. Cephalometric measurements and facial deformities in subjects with beta-thalassemia major. Eur J Orthod. 2002;24(1):9-19

24. Bhardwaj VK, Veeresha KL, Sharma KR. Prevalence of malocclusion and orthodontic treatment needs among 16 and 17 year-old school-going children in Shimla city. Himachal Pradesh Indian J Dent Res. 2011;22(4):556-60

25. Shivakumar KM, Chandu GN, Subba Reddy W, Shafiulla MD. Prevalence of malocclusion and orthodontic treatment needs among middle and high school children of Davangere city, India by using Dental Aesthetic Index. J Indian Soc Pedod Prev Dent. 2009;27(4):211-8.

26. Esa R, Razak IA, Allister JH. Epidemiology of malocclusion and orthodontic treatment need of 12-13-year-old Malaysian schoolchildren. Community Dent Health. 2001;18(1):31-6.

27. Van Wyk PJ, Drummond RJ. Orthodontic status and treatment need of 12-year-old children in South Africa using the Dental Aesthetic Index. SADJ. 2005;60(8):334-6. 338.

28. Ugur T, Ciger S, Aksoy A, Telli A. An epidemiological survey using the Treatment Priority Index (TPI). Eur J Orthod. 1998;20(2):189.

\section{Submit your manuscript to a SpringerOpen ${ }^{\circ}$ journal and benefit from:}

- Convenient online submission

- Rigorous peer review

- Immediate publication on acceptance

- Open access: articles freely available online

- High visibility within the field

- Retaining the copyright to your article

Submit your next manuscript at $\gg$ springeropen.com 